Informasi - ISSN (p) 0126-o650; ISSN (e) 2502-3837

Vol. 49, No. 2 (2019), pp. 91-10o doi: http://doi.org/10.21831/informasi.v49i2.28256

\title{
CHALLENGES OF A DUAL ROLE OF MARKETING PUBLIC RELATIONS AND PUBLIC RELATIONS IN DEVELOPING A POSITIVE IMAGE OF PT OVERSEAS ZONE
}

\author{
Siti Khopipah \\ opiemananis@gmail.com \\ Prodi Manajemen Komunikasi, Fakultas Ilmu Sosial dan Manajemen \\ Institut Ilmu Sosial dan Manajemen STIAMI, Indonesia
}

Ade Tuti Turistiati

ade.tuti@amikompurwokerto.ac.id

Prodi Ilmu Komunikasi, Fakultas Bisnis dan Ilmu Sosial,

Universitas Amikom Purwokerto, Indonesia

\begin{abstract}
The terms Marketing Public Relations and Public Relations are sometimes used interchangeably. However, actually the two roles are different. The purpose of this study is to analyse a dual role of Marketing Public Relations (MPR) and Public Relations (PR) in building a positive image of PT. Overseas Zone Education Consultant or PT. This research method uses a descriptive qualitative approach. Data collection techniques use observation, in-depth interviews, literature studies from books and relevant articles or documents. Researchers observed the Head of MPR who also plays a role as a PR in carrying out her daily work activities. In-depth interviews were conducted to 6 informants, namely the Head of MPR, the owner and head of the company, the Head of Consultant, 1 staff member, and 2 clients / customers. The results of this study show that Marketing Public Relations of PT. Overseas Zone carries out the process of planning and evaluating programs that can encourage purchases through an effective and trustworthy communication in conducting publications (special events). Strategies to support the role of Marketing Public Relations, namely through pull strategy, push strategy, and pass strategy. The dual role of MPR and PR that are occupied by a Head of MPR has obstacles in PT. Overseas Zone such as time constraints that cannot be managed properly in holding special events, more work, and fatigue because the energy devoted to these two roles is very large, the work is less optimal. This obstacle is a challenge for the Head of MPR who also act as a PR in building a positive image of the company. The company's image is very dependent on the performance of the MPR. The solution made in overcoming obstacles in building a positive image of PT. Overseas Zone is to build good cooperation between the Head of MPR and education consultants. In addition, the company makes a new breakthrough by providing a study package product abroad that is different from other educational consulting services and target markets tailored to customer needs.
\end{abstract}


Istilah Marketing Public Relations dan Public Relations kadang-kadang digunakan secara bergantian. Namun, sebenarnya kedua perannya berbeda Tujuan penelitian ini untuk menganalisis peran ganda Marketing Public Relations (MPR) dan Public Relations (PR) dalam membangun citra PT. Overseas Zone atau Overseas Zone Education Consultant. Metode penelitian ini menggunakan pendekatan kualitatif deskriptif. Teknik pengumpulan data menggunakan teknik observasi, wawancara mendalam dan studi literature. Peneliti melakukan observasi terhadap Head of MPR yang juga berperan sebagai $P R$ dalam melaksanakan aktivitas pekerjaannya seharihari. Wawancara mendalam dilakukan terhadap 6 informan, yaitu Head of MPR, pemilik sekaligus pimpinan perusahaan, Head of Education Consultan, 1 orang staf, dan 2 orang client/customer. Hasil penelitian ini menunjukkan bahwa Marketing Public Relations di PT. Overseas Zone melakukan proses perencanaan dan evaluasi program-program yang dapat mendorong pembelian melalui komunikasi yang efektif dan dapat dipercaya dalam melakukan publikasi (special event). Strategi untuk mendukung peran Marketing Public Relations, yaitu melalui pull strategy, push strategy, dan pass strategy. Peran ganda MPR dan PR yang diampu oleh seorang Head of MPR memiliki hambatan di PT. Overseas Zone seperti kendala waktu yang kurang dapat dikelola dengan baik dalam mengadakan special event, pekerjaan lebih banyak, dan kelelahan karena tenaga yang tercurah untuk kedua peran tersebut sangat besar, hasil pekerjaan kurang optimal. Hambatan tersebut merupakan tantangan bagi Head of MPR yang merangkap sebagai PR dalam membangun citra positif perusahaan. Citra perusahaan sangat tergantung dari kinerja MPR. Solusi yang dilakukan dalam mengatasi hambatan dalam membangun citra positi PT. Overseas Zone adalah membangun sinergi yang baik antara Head of MPR dengan Head of Education Consultant. Selain itu, perusahaan membuat terobosan baru dengan menyediakan produk paket studi ke luar negeri yang berbeda dengan jasa konsultasi pendidikan lain dan target market disesuaikan dengan kebutuhan pelanggan.

Keywords: Dual roles, Marketing Public Relations, Education, Breakthrough

\section{INTRODUCTION}

An overseas education consulting service company is a form of educational institution that accommodates Indonesian students to study abroad. The company is also known as an education consultant. Nowadays, education consultants are increasingly growing in Indonesia. This condition can be seen from the increasing number of overseas consulting service companies that have sprung up in Jakarta and major cities throughout Indonesia such as Surabaya, Bandung, and Medan.

Based on the study of the Indonesian International Educational Consultants Association, there are more than 50 thousand Indonesian students who study abroad each year. Australia, New Zealand, UK, USA, and China are the destination countries that are in great demand among Indonesian students
(Kabar 6, 2018).

Recently, demands are increasingly diverse. Previously people still did not know how to obtain comprehensive information about education abroad. People were confused about which universities, what majors, accommodation, how much it costed, and so on (Lidwina, 2019). Overseas education consulting service companies, one of which is PT. Overseas Zone Education Consultant (PT. Overseas Zone) helps people who want to continue their education abroad. The assistance starts from the beginning to the end, even until students graduate and return to Indonesia. Good service makes PT. Overseas Zone has become a company with a positive image from the community, especially from customers who have been helped with the management of their studies abroad. 
The positive image of PT. Overseas Zone cannot be separated from the role of Public Relations (PR), which has a function to maintain a good relationship between the company and the society. PT. Overseas Zone formally does not have a PR department. However, functionally there is a Head of Marketing Public Relations (MPR) who plays a dual role as a PR. The Head of MPR becomes the liaison between the company and the community and carries out activities that support marketing.

In carrying out its external function, Marketing Public Relations of PT. Overseas Zone does activities that support marketing activities such as publicity, presentations, seminars, exhibitions, making brochures, making events or activities, promoting via the internet, and others. The purpose of these activities is to make the products of PT. Overseas Zone is increasingly known by the public. If the public know the product of the company, an opportunity to introduce overseas education consulting services will be more extensive.

Conceptually, MarketingPublicRelations has a role in achieving organizational goals such as: developing consumer awareness of the product being launched; building consumer awareness of the company's image or benefits of the products offered/used; encouraging enthusiasm through a sponsor articleabout the use and benefits of a product; In addition, MPR activities are also able to reduce the cost of promoting commercial advertisements, both in electronic and print media and so on, to achieve cost efficiency (Gani, 2017)

To face the increasingly fierce competition in overseas education consulting services, an appropriate alternative strategy is needed. It is indicated as the most effective way to utilize the power of public relations for marketing activities which is known as Marketing Public Relations (MPR).

Through the MPR, it is expected that cooperation can be established and finally the formation of a positive image for overseas education consulting services companies can be achieved. The goal is to provide services to customers so that customers feel comfortable and satisfied with the services of PT. Overseas Zone. By doing so, customers will not move to other overseas education consulting services.

Marketing Public Relations needs to take appropriate and effective steps to overcome the competition. MPR has to look at the company's external and internal environment. In additions, the importance of PT. Overseas Zone has a positive image is to gain the trust of its customers. PT. Overseas Zone also need to find out whether its product of education services has an advantage or not because to win the competition, product excellence is a must and must have. To produce an excellence products, a good or positive image of the company is very important. As a matter of fact people still prioritize not only the best product but also the best service. If the company has a positive image, the community will trust and use the company's services.

Marketing Public Relations plays role in carrying out its functions in publication activities and giving a good image to public. However, the Head of MPR at PT. Overseas Zone faces several problems related to her dual role as MPR and PR. Many things cannot be done because of limited manpower, time, and costs incurred by PT. Overseas Zone to carry out activities, lack of relations with the media, and less even almost never carry out CSR activities.

Based on the above phenomenon, the authors are interested in analysing the challenges of the dual role of Marketing Public Relations (MPR) and Public Relations (PR) that is carried out by the Head of MPR in building a positive image of PT. Overseas Zone.

\section{LITERATURE REVIEW}

Many previous studies on Marketing Public Relations (MPR) have been carried out. The locus of the research is diverse, for example banks, hotels, villas, travel, malls, and e-commerce companies. Research on the MPR in education institutions/agents has been rarely done. The research methods used 
in the study were also different, including qualitative descriptive research methods, case studies, and quantitative with technical surveys.

Abdillah in his research with survey methods measured the extent to which Marketing Public Relations (MPR) related to the Smartfren brand image. The perception of educated customer groups was used to measure the role of the MPR. Respondents were selected through purposive sampling on 100 students of the Faculty of Economics, Ibnu Khaldun University, Bogor. Based on the results of his research, Abdillah showed that Smartfren publications were Marketing Public Relations activities that got the best response. Smartfren is a CDMA brand that is the top of mind in consumer perception (Abdillah, 2017).

The results of Setyahesti's research showed that the strategy undertaken by MJ Travael's Marketing Public Relations used strategies that utilized social media as a promotional tool. This strategy used because at present public are more interested in and dependent on social media applications such as Facebook and Twitter (Setyahesti, 2012).

Widayawati's research showed that Swiss Bel Hotel Borneo Samarinda carried out a number of strategies that can increase the number of customers, namely through planning, implementation, and accompanied by covering ${ }_{4} \mathrm{P}$ and mixed through products, prices, promotions, places, participants and processes. The strategy adopted by the Swiss Bel Hotel Borneo Samarinda turned out to be its success in increasing the number of customers which is quite successful and good for other hotel examples, as evidenced by the incensement of the number of occupancy rates each year (Widayawati, 2016)

Murdaniati and Widodo's research results showed that the strategy undertaken by MATOS Mall was through the concept of Marketing Public Relations (MPR) with various programs such as push, pull, and pass strategies. The driving factor of business partners is to create internal and external activities. Internal activities by doing things inside the MATOS Mall while the external activities are outside the MATOS Mall (Murdaniati \& Widodo, 2018)

Santoso and Rezeky's research showed that the changes made by HSBC management to HSBC Indonesia did not use the term merge with Bank Ekonomi. However, in the form of integration the mixing of the two banks become one service under HSBC Indonesia. This rebranding process utilizes various mass media by doing special events such as roadshows in 5 major cities like Jakarta, Bandung, Surabaya, Medan, and Makassar (Santoso \& Torua, 2018)

The results of previous studies above showed that Marketing Public Relations plays an important role in building the company's image, branding, as well as performance. Social media is one of the media used in carrying out Marketing Public Relations activities.

Public Relations is a continuous process of management effort. Public Relations aims to get an understanding from customers, the general public including its staff. Public Relations has internal and external processes. The process is to make improvements through corporate culture such as discipline, motivating, improving services and work productivity in order to create a sense of belonging to the company. Outward process, trying to create trust and corporate image. In addition, the process goes out to maintain the image of its products (Ruslan, 2005)

Public relations in general is an interaction carried out by two parties which will then create an advantage for both parties. Specifically public relations is a relationship which in the end is very useful for building a communication, cooperation and support relationship between one another.

The role of Public Relations (PR) according to (Ruslan, 2005) is as a communicator or liaison between the organization or institution represented by the public; fostering relationships, which seeks to foster positive and mutually beneficial relationships with the public, acting as backup of management, namely as a supporter in the company's management function; shape 
the image of the company.

Marketing Public Relations (MPR) according to Philip Kotler was created to add or provide value to the product through a unique ability to show the credibility of the product message (Kotler, 2009). The concept of Marketing Public Relations includes a three-way strategy to implement the program in achieving its objectives, namely a push strategy to stimulate (encourage) purchases while providing added value or satisfaction for customers (satisfied customers) that have use company products; Pull strategy or attractive strategy, that public relations is the potential to carry a tactic to attract attention in various ways to achieve company goals and increase sales in the form of services or goods; Pass strategy or influencing strategy is as an effort to create a public image generated through various activities and participation in community activities or social responsibility, as well as awareness of issues related to social conditions (Ruslan, 2010).

Marketing Public Relations is a synergy between the implementation of marketing strategy with the activities of the Public Relations work program in an effort to expand marketing and to achieve customer satisfaction. According to Philip Kotler in (Ruslan, 2005). Marketing Public Relations covers the following roles: 1) Growing costumer awareness of the product being launched. Build consumer confidence in the company's image or the benefits of the products offered or used. Encourage enthusiasm (sales force) through an article sponsor (advertorial) about the use and benefits of a product. Reducing the cost of promotion (advertising), both printed and electronic media for the achievement of cost efficiency; 2) Commitment to improve services to consumers, including efforts to overcome complaints (complaint handling) and others for the achievement of customer satisfaction; 3) Campaign for launching new products and planning changes in the position of the same product; 4) Consuming continuously through Public Relations media about activities and work programs related to social and environmental care until a positive publications according to the public is created. 5) Fostering and maintaining the image of the company or products and services in terms of the quality and quantity of services provided to consumers. 6) Trying to be proactive in anticipating negative events that have the potential to arise.

Katz (Ardianto \& Sumirat, 2004) explained that image is how another party sees a person, a committee, a company or an activity. Image is the impression obtained through one's knowledge and experience of something. The company has the characteristics, identity and values that are maintained by the society. Meanwhile, according to Jefkins the image is an opportunity as an impression, image or impression that is right (in accordance with actual reality) regarding various policies of personnel, products, or services of an organization or company (Jefkins, 2003).

Kasali defines an image as an impression that arises because of an understanding of reality. The understanding itself arises because of the information (Kasali, 2003).

There are various kinds of images, one of which is corporate image. Corporate image is a type of image related to the figure of the company as its main goal, how to create a positive corporate image, better known and accepted by the public, excellent service quality, success in marketing, and to the extent related to social responsibility and others.

Corporate image is formed based on the stakeholders' perceptions of specific company actions as well as associated industry and nation issues. An organisation's image to a large extent influences stakeholders' reactions to specific corporate actions and products (Adeniji, Osibanjo, Abiodun, \& Oni-Ojo, 2015).

\section{METHODS}

This study uses qualitative methods to understand the phenomenon of the dual role of Marketing Public Relations (MPR) and Public Relations in building a positive image of PT. Overseas Zone. The author's consideration in choosing a qualitative approach because the qualitative approach 
discusses in depth to understand phenomena about the behavior, opinions, attitudes, responses, feelings, desires and wishes of a person or group (company).

The types of data required in this study include primary data and secondary data. The data were collected by interview and documentation techniques. This study employed semi-structured interviews, because it can direct the interview more closely, to have a pre-determined set of questions while simultaneously allowing the interviewees sufficient flexibility to shape the flow of information given (Wilkinson \& Birmingham, 2003).

All data collection activities were obtained from trusted and related sources from PT. Overseas Zone. The data collection techniques through observation, in-depth interviews with the company, clients, and through documentation. Research informants from internal company (the owner/leader of the company, Head of MPR, Head of Consultant, Staff) and 2 other company's clients/customers. The customer was chosen to find out the perspective of external personnel about the services provided by PT. Overseas Zone during the event and consultation with the Overseas Zone.

\section{RESULT AND DISCUSSION}

PT. Overseas Zone Education Consultant (PT. Overseas Zone) was established in 2002. The institution is engaged in consulting education to study abroad. Its head office is in Jakarta. Its branch office is located in Surabaya. Services at PT. Overseas Zone is a top priority for anyone who comes and needs information about studying in various countries, such as the United States, Canada, Australia, United Kingdom, New Zealand, Paris, Japan, Malaysia, and Singapore.

PT. Overseas Zone has helped hundreds of Indonesian students studying at various overseas universities and colleges for more than 10 years. These students study with a variety of majors and from various levels of education, such as high school, certificates, diplomas, degrees and masters. PT. Overseas
Zone has received several awards, such as being appointed as a reference agent from the Australian Catolic University, the Holmes Institute, and Navitas. PT. Overseas Zone also received a Certificate of Incorporation from the New Zealand government and an EATC Certificate from the Australian ambassador in Malaysia, as a consular agent of quality education ("Overseas Zone Education Consultant," 2019).

\section{The Dual Role of the Head of Marketing Public Relations at PT. Overseas Zone}

The success of PT. Overseas Zone get a variety of achievements and awards can not be separated from the role of Marketing Public Relations (MPR). According to the Head of MPR, MPR plays a major role in introducing PT. Overseas Zone to public. The Head of MPR carried out publication, promotion and cooperation activities with outside parties who support the MPR's activities. The Head of Marketing Public Relations has a dual role, MPR and PR.

Based on an interview with Mike Sky as the leader of PT. Overseas Zone, it is found out that separating Public Relations from Marketing Public Relations is not necessary. It incurs additional costs such as monthly salaries and other allowances. Marketing Public Relations at PT. Overseas Zone is considered to have represented most of the roles and functions of the Public Relations themselves. However, according to Dita, as Head of Marketing Public Relations, which carries out the dual functions as PR and Public MPR, the dual function makes many things can not be done optimally because of limited time, extra energy, and difficulty to manage workload.

The role and function of public relations carried out by the Head of Marketing Public Relations at PT. Overseas Zone including: introducing PT. Overseas Zone to the public as an external party through publication activities; establish cooperation with outside parties such as course institutions, hospitals, overseas campuses, and other parties who support each other for mutual beneficial cooperation; holding a special event that 
connects the community with PT. Overseas Zone; liaise with the media as a support in reporting PT. Overseas Zone, especially during educational exhibition activities; maintain good relations with customers of PT. Overseas Zone by making a gathering.

The role and function of the MPR is carried out by the Head of Marketing Public Relations at PT. Overseas Zone includes searching for markets for publication and promotion activities in major cities throughout Indonesia; marketing study package products abroad PT. Overseas Zone through various activities such as special events, promotions through print media advertisements, billboards, banners, and internet media such as websites, google adwards, forums, instagram, and Facebook to get prospective customer data; making advertising material for promotion. In carrying out publication and promotion activities, the Head of Marketing Public Relations conceptualizes the planning and evaluation process of the program that stimulates customer purchases and positive images.

The concepts carried out by the Head of Marketing Public Relations when conducting publications and promotions, especially in special events, include: Planning (planning what will be done at a special event); Budgeting (detailing the budget costs incurred when going to run a special event); Targeting (target number of audiences who come at special events, for example the seminar target must be at least 200 people, and the education exhibition target there must be 1,ooo people); Services (excellent service provided to prospective customers who come to special events, from the beginning to the end of the event); Invite resource persons (bring competent speakers in their fields directly from overseas campuses in accordance with their school programs so that events are more attractive, and prospective customers are more confident and trust that what is conveyed by PT. Overseas Zone through publication by Marketing Public Relations is true and in accordance with their sources; Evaluating
Program (Evaluation of special events that have been carried out with the aim to find out and evaluate any deficiencies in special events that have been carried out, so that future events that will be carried out can run well and optimally.

\section{MPR's Barriers in Building the Positive Image of PT. Overseas Zone}

In carrying out its roles and functions, the Head of Marketing Public Relations experiences obstacles, including: in terms of work it is difficult to find customers, in terms of the products offered they do not meet with the customer expectation, time constrain, extra energy and work management are more numerous and complicated.

"The obstacle when promoting products is, sometimes we find it difficult to find a market of people who are interested in studying abroad with a large population of people in Indonesia, around hundreds of millions of people, while the cost of education abroad is quite large, so not all are willing and able to learn outside. "(Dita, Head of MPR)

In terms of products: Products that are promoted are sometimes not suitable for the market because they are new, so they don't get a response from the public.

"In terms of products also sometimes like not in accordance with the Indonesian market, because most Indonesians want schools with low cost but quality." (Dita, Head of MPR)

Mike Sky as the owner/leader of PT. Overseas Zone confirms:

"For obstacles there must be, almost every thing we do there must be obstacles. For example when issuing study packages abroad, usually not all people receive or respond to the products delivered. However, we must always try first, whether the products are released according to the Indonesian market or not."

Solutions in Overcoming Obstacles in Building the Image of PT. Overseas Zone Head of Marketing Public Relations explained that 
so that customers are interested in using the services of PT. Overseas Zone, the company provides different package products with other educational consulting services that are not yet known by the public. For example, a pilot study package abroad, a study package while carrying a family, study package while learning golf, study package abroad package (the plan).

According to the owner/leader of PT. Overseas Zone target market tailored to the needs of the community. For example, the pilot target package for the market is men under the age of forty. The study package while bringing the main target market of the market is a married couple with a degree, both those who have children and those who do not have children. The study package while learning golf is the main target market for elementary/middle school age children. The overseas study installment package (the plan) is the main target market for customers who will study abroad in the next 1-5 years. The advantage of the overseas study installment package is that the price is binding or there is no increase in the price of school fees even though it is still a long time off.

PT. Overseas Zone makes advertising material as attractive as possible without any exaggeration, so that the public believes in the services of PT. Overseas Zone. The company carries out special event activities such as seminars which are held every month, and educational exhibitions every year to bring PT. Overseas Zone with the community. The goal is that the study package products abroad reach the community. By attending an event held by Public Relations Marketing, people are encouraged to study abroad. Marketing Public Relations collaborates with consultants/customer service to deliver study information outside the country at the time of the event. Consultants/customer services conduct direct selling by "consultation one by one" to the people who visit the event and want to know more about how to study abroad the conditions.

Based on the results of the study, the methods undertaken by Marketing Public Relations are in accordance with Philip
Kotler's three ways strategy tactics. The Three Ways Strategy, to implement the program in achieving goals (goals), namely first that public relations is the potential to carry a pull strategy tactic (attractive), second is the power strategy (strength) as a push strategy (to encourage) in terms of marketing. The third tactic is the pass strategy (persuasion) as an effort to influence or create favorable public opinion.

Marketing Public Relations PT. Overseas Zone carries out various publication activities to get prospective customers who will study abroad with various levels of education ranging from kindergarten, elementary, junior high school, high school, Certificate, Diploma, Bachelor $\left(\mathrm{S}_{1}\right)$, Master $\left(\mathrm{S}_{2}\right)$.

"To introduce PT. Overseas Zone to the community, we usually do activities. Most of what we do is by organizing special events such as seminars and exhibitions, as well as promoting through the internet media, especially websites, google adwards, instagram and facebook. That's the most effective way for publication and promotion." (Dita, Head of MPR)

PT. Overseas Zone is thinking of ways and trying to market new package products. The next step taken is to think about, discuss and try to market the product package made, because if you haven't tried it, you won't know whether the product will be accepted by the community or not. Then, always correct the mistakes or rejections from the community. PT. Overseas Zone does not see other companies in the same field as what is done, but rather focuses on what will be done, especially services to prospective customers as needed. The company looks more at the needs of prospective customers and tries to provide what is needed. The company also makes improvements internally and externally. From the internal side of the company doing process improvements, such as administrative processes, student flow processes, so that the process is faster, not only from the customer side but in terms of human resources (employees). Get closer to people who think positively and avoid those 
who think negatively, focus on one thing in accordance with the goals of PT. Overseas Zone. From external parties the company tries to do good relations with the media (media relations) and customers.

Marketing Public Relations at PT. Overseas Zone began in 2012. There are differences in terms of registering customers studying abroad. For prior registration, the role of the MPR is an average of 10 students per month. After the role of the MPR became an average of 20 students per month. This was confirmed by Ica as the Head of Consultant:

"Marketing Public Relations at PT. Overseas Zone is very helpful in the consultant department, which was once an application for student registration who study abroad an average of 10 people per month, to an average of 20 people per month".

The position of Marketing Public Relations at PT. Overseas Zone has a dual role, namely carrying out the role and function as PR and MPR. This dual role makes the office holders less effective in carrying out their work. In otherwords, the MPR incumbent will potentially have far better work performance if it does not play a role as a PR.

Ica added:

"If the Head of the MPR focuses on his work while there are additional personnel as homework, I am sure there are more than 20 students enrolled."

Opinions from MPR office holders and educational consultants directly related to customers reinforced the need for MPR and PR to be separated. The realization depends very much on the owner and company leader.

\section{CONCLUSION}

From the analysis above, it can be concluded that the dual role of Marketing Public Relations (MPR) and Public Relations face some problems in building a positive image of PT. Overseas Zone. The dual role of MPR and PR by Head of MPR caused some obstacles such as time constraints that cannot be managed properly in holding special events and exhausting because the energy devoted to these two roles is very large. However, separating the two roles on two employees will add costs to the company. Its solution is that the Head of MPR collaborates with Head of Consultant in many events by providing a study abroad product package that is different from other educational consulting services, which are not yet known to the public such as overseas study package of pilot, study package with carrying families, and study packages while learning golf. The target market is adjusted based on the needs of the customers, namely by launching product packages that are not yet on the market, making advertising materials as attractive as possible without any exaggeration, doing special events, and others. Those collaborations develop a positive image of PT. Overseas Zone.or future research, the authors recommend a more in-depth and specific analysis of the dual role of MPR and PR by using a different approach so that the result of the research is more comprehensive. For future research, the authors recommend a more in-depth and specific analysis of the dual role of MPR and PR by using a different approach so that the result of the research is more comprehensive.

\section{REFERENCES}

Abdillah, F. (2017). Efektivitas marketing publicrelationsdalammembanguncitra merek perusahaan jasa telekomunikasi. Ecodernica STIE Pandu Madania Bogor. 1(1), 6-7.

Adeniji, A. A., Osibanjo, A. O., Abiodun, A. J., \& Oni-Ojo, E. E. (2015). Corporate image: A strategy for enhancing customer loyalty and profitability. Journal of South African Business Research, 1-12.

Ardianto, E., \& Sumirat, S. (2004). Dasardasar public relations (3rd ed.). Bandung: Rosda Karya.

Gani, P. K. (2017). Marketing public relations. Retrieved from http://www.lspr.edu/ pritakemalgani/marketing-publicrelations/

Jefkins, F. (2003). Public relations. Jakarta: 
PT. Gelora Aksara Pratama.

Kabar 6. (2018). Jumlah pelajar indonesia yang sekolah ke luar negeri meningkat. https://kabar6.com/jumlah-pelajarindonesia-yang-sekolah-ke-luarnegeri-meningkat/

Kasali, R. (2003). Manajemen public relations: konsep dan aplikasinya di Indonesia. Jakarta: PT. Pusaka Utama Grafiti.

Kotler, P. (2009). Manajemen pemasaran, analisis, perencanaan, implementasi dan kontrol. Jakarta: PT. Prenhalindo.

Lidwina, A. (2019). Mana yang lebih baik, kuliah di Indonesia atau luar negeri? Retrieved from Ruang Guru website: https://blog.ruangguru.com/manayang-lebih-baik-kuliah-di-indonesiaatau-luar-negeri

Murdaniati, K., \& Widodo, H. P. (2018). Strategi marketing public relations MATOS Mall dalam menjaga mitra bisnis. Jurnal Ilmu Sosial dan Politik, Universitas Tribhuwana Tunggadewi Malang., 7(1), 44-46.

Overseas Zone Education Consultant. (2019). Retrieved from https://overseaszone. com/page/About-Us

Ruslan, R. (2005). Kampanye public relations. Jakarta: Raja Grafindo Persada.

Ruslan, R. (2010). Manajemen public relations dan media komunikasi. Jakarta: Raja
Grafindo Persada.

Santoso, P.Y., \&Toruan, R. R. M.(2018).Strategi marketing public relations dalam rebranding HSBC Indonesia untuk membentuk brand awareness. Jurnal Pustaka Komunikasi, 1(1), 1-14.

Setyahesti, R. (2012). Strategi marketing public relations dalam membentuk citra perusahaan di mata customer (studi kualitatif deskriptif pada MJ travel Malang). Jurnal Komunikasi, Universitas Brawijaya Malang., 5(2), 10-12.

Widayawati. (2016). Strategi marketing public relations Swiss Bell Hotel Borneo Samarindadalammeningkatkanjumlah pelanggan. EJurnal Ilmu Komunikasi, FISIP Universitas Mulawarman., 4(3), 1-2.

Wilkinson, D., \& Birmingham, P. (2003). Using research instruments: a guide for researchers. UK: Routledge Study Guides. 